\title{
Expansion and Enrichment of Gamma-Delta $(\gamma \delta)$ T Cells from Apheresed Human Product
}

Ana Marie Landin ${ }^{1}$, Cheryl Cox ${ }^{1}$, Bin Yu $^{2}$, Nelli Bejanyan ${ }^{1,2}$, Marco Davila $^{1,2}$, Linda Kelley ${ }^{1,2}$

${ }^{1}$ Cell Therapy Facility, Moffitt Cancer Center and Research Institute ${ }^{2}$ Department of Immunology, Moffitt Cancer Center and Research Institute

\section{Corresponding Author}

Ana Marie Landin

Ana.Landin@Moffitt.org

\section{Citation}

Landin, A.M., Cox, C., Yu, B.,

Bejanyan, N., Davila, M.,

Kelley, L. Expansion and Enrichment

of Gamma-Delta $(\gamma \delta)$ T Cells from

Apheresed Human Product. J. Vis.

Exp. (175), e62622, doi:10.3791/62622 (2021).

\section{Date Published}

September 22, 2021

DOI

$10.3791 / 62622$

URL

jove.com/video/62622

\section{Abstract}

Although $\mathrm{V} \gamma 9 \mathrm{~V} \delta 2 \mathrm{~T}$ cells are a minor subset of $\mathrm{T}$ lymphocytes, this population is sought after for its ability to recognize antigens in a major histocompatibility complex (MHC)independent manner and develop strong cytolytic effector function that makes it an ideal candidate for cancer immunotherapy. Due to the low frequency of Gamma-Delta $(\mathrm{\delta}) \mathrm{T}$ cells in the peripheral blood, we developed an effective protocol to greatly expand a highly pure $y \delta T$ cells drug product for first-in-human use of allogeneic $ү \delta$ T cells in patients with acute myeloid leukemia (AML). Using healthy donor apheresis as an allogenic cell source, the lymphocytes are isolated using a validated device for a counterflow centrifugation method of separating cells by size and density.

The lymphocyte-rich fraction is utilized, and the $ү \delta$ T cells are preferentially activated with zoledronic acid (FDA-approved) and interleukin (IL)-2 for 7 days. Following the preferential expansion of $y \delta T$ cells, a clinical-grade magnetic cell-separation device and TCR $\alpha \beta$ beads are used to deplete contaminating T-cell receptor (TCR) $\alpha \beta$ $T$ cells. The highly enriched $y \delta T$ cells then undergo a second expansion using engineered artificial antigen-presenting cells (aAPCs) derived from K562 cellsgenetically engineered to express single-chain variable fragment (scFv) for CD3 and CD28, 41BBL (CD137L) and IL15-RA-together with zoledronic acid and IL-2. Seeding all day-7 enriched $ү \delta ~ T$ cells in co-culture with the aAPCs facilitates the manufacture of highly pure $ү \delta$ T cells with an average fold expansion of $>229,000$-fold from healthy donor blood.

\section{Introduction}

Leukemia relapse is the leading cause of mortality after hematopoietic cell transplantation (HCT) in patients with $\mathrm{AML}^{1,2,3}$. Better leukemia-free survival was reported with the increased recovery of blood $ү \delta$ T cells after HCT without increased risk of Graft-versus-Host Disease (GVHD) ${ }^{4}$. The ability of $y \delta T$ cells to recognize antigens in an MHCindependent manner and develop strong cytolytic and Th1like effector functions make this minor subpopulation of T cells 
ideal for the treatment of $A M L$ patients undergoing allogeneic transplantation at risk for relapse ${ }^{5}$. Given that the Vy9Vס2 T cells are a minor subset of T lymphocytes ranging from $0.5 \%$ to $5 \%$ of $\mathrm{T}$ cells in the periphery ${ }^{6}$, we set out to establish a robust system to expand this rare population of blood cells to achieve potentially therapeutic doses for clinical trials.

Although others have successfully expanded $ү \delta \bar{T}$ cells using zoledronic acid and even aAPCs, we have developed a process that can potentially expand $\gamma \delta \mathrm{T}$ cells by $229,749-$ fold. The expansion is biphasic: first, lymphocytes are obtained by elutriation using the separation instrument. The equipment provides a closed system that allows the separation of cells based on their size, shape, and density by counterflow centrifugation. After enriching for lymphocytes, selective expansion of $\mathrm{V} y 9 \mathrm{~V} \delta 2 \mathrm{~T}$ cells is achieved by treatment with zoledronic acid and IL-2 for 7 days. Immediately following this treatment, TCR- $\alpha \beta \quad T$ cells are depleted using microbead technology, allowing for subsequent expansion of the $y \delta T$ cells with K562-derived aAPCs.

For process validation, only $5 \times 10^{6}$ zoledronic acidexpanded $y \delta T$ cells were used for the phase-2 coculture expansion with aAPCs. In this second phase of expansion, $y \delta T$ cells are activated using a current Good Manufacturing Practices (cGMP)-compliant Working Cell Bank (WCB) of genetically engineered K562-derived aAPCs (K562VL6(scFv-CD3-41BBL;scFv-CD28-IL15-RA)) manufactured at Moffitt. The rationale of this biphasic expansion is based on the ability of zoledronic acid to inhibit farnesyl diphosphate synthase (FDPS) in monocytes, leading to the accumulation of isopentenyl pyrophosphate, which directly stimulates the $\mathrm{V} 2 \mathrm{~V} \delta 2$ cells. In the second phase of expansion, the K562-derived aAPCs
(K562VL6(scFv-CD3-41BBL;scFv-CD28-IL15-RA)) provide a robust stimulation to all T cells. However, the cell product has already been enriched for the $y \delta \mathrm{T}$ cells, resulting in a robust expansion of the $\gamma \delta \mathrm{T}$ cells.

With the use of specific equipment and flasks, the process is a functionally closed system, thus decreasing the risk of contamination. In addition, the $1 \mathrm{~L}$ closed-system bioreactor facilitates maximal growth and expansion of cells in a total volume of $1 \mathrm{~L}$ of medium with minimal need for feeding. The advantage of the Moffitt method is that it provides a rapid, reproducible, and highly feasible GMP system to produce a highly pure, donor-derived $y \delta \mathrm{T}$ cell product for allogeneic administration. This method can be applied to any clinical trial that aims at using human $ү \delta T$ cells expressing $\vee_{\gamma} 2 \mathrm{~V} \delta 2 \mathrm{~T}$ cell receptors as adoptive immunotherapy to mediate immunity against microbes and tumors in cancer patients with partial and complete remission. In addition, it provides a robust platform for the development and production of $\mathrm{\delta}$ chimeric antigen receptor-positive $\left(\mathrm{CAR}^{+}\right) \mathrm{T}$ cells.

\section{Protocol}

NOTE: IRB approval was obtained, and informed consent was obtained from the donors.

\section{Lymphocyte isolation}

1. Transfer the apheresis product to a clean room.

NOTE: Process validation was performed using normal donor apheresis from an external commercial vendor compliant with raw cellular material collection regulations.

2. Collect samples for sterility testing, cell count, and cell phenotyping. 
3. Elutriate on the counterflow centrifugation device using a primary medium of Hanks Balanced Salt Solution with $1 \%$ human serum albumin (HSA) and a secondary medium of saline solution $(0.9 \%$ sodium chloride Injection USP) or Dulbecco's Phosphate-Buffered Saline (DPBS). Set the elutriation centrifugation speed at $900 \times$ $g$ and collect fractions based on flow rate and time.

4. Collect samples from fraction 2 and perform the following tests: $2 \mathrm{~mL}$ for sterility testing; $0.5 \mathrm{~mL}$ for cell count and viability using acridine orange/propidium iodide (AO/PI); $5 \times 10^{6}$ cells for cell phenotyping by flow cytometry.

5. Expand a pure lymphocyte fraction (fraction 2) of cells in culture at $10 \times 10^{6} \mathrm{cells} / \mathrm{cm}^{2}$ in a $1 \mathrm{~L}$ closed-system bioreactor with $5 \mu \mathrm{mol} / \mathrm{L}$ of zoledronic acid and $300 \mathrm{IU} /$ $\mathrm{mL}$ of IL-2.

6. Incubate for seven days in an incubator set at $37^{\circ} \mathrm{C}$ with $5 \% \mathrm{CO}_{2}$

\section{Alpha-beta $(\alpha \beta)$ T cell depletion}

1. Harvest cells from the $1 \mathrm{~L}$ closed-system bioreactor flask. Sterile-weld a $1 \mathrm{~L}$ transfer pack to the red line of the closed-system bioreactor, and use the appropriate pharmaceutical pump to transfer the cells into the transfer pack.

2. Take the following samples: $10 \mathrm{~mL}$ for spent medium sterility; $0.5 \mathrm{~mL}$ of cells for cell count and viability using AO/PI; $5 \times 10^{6}$ cells for flow cytometry

3. Resuspend the cells at $\sim 5 \times 10^{8}$ cells $/ \mathrm{mL}$ in phosphate-buffered saline (PBS) or (PBS/ ethylenediaminetetraacetic acid (EDTA)) buffer $+0.5 \%$ HSA and biotinylated TCR $\alpha \beta$-specific antibody.
4. Place the shaker in the refrigerator and incubate the cells at $2-8{ }^{\circ} \mathrm{C}$ for approximately 15 min with shaking.

5. Wash the cells with a total of $600 \mathrm{~mL}$ of PBS/EDTA buffer $+0.5 \%$ HSA. Centrifuge to remove the unbound antibody at $200-500 \times g$ for $15 \mathrm{~min}$ at $2-8{ }^{\circ} \mathrm{C}$. Resuspend $\sim 5 \times$ $10^{8}$ cells $/ \mathrm{mL}$ in PBS/EDTA buffer $+0.5 \%$ HSA with antibiotin-specific microbeads $(7.5 \mathrm{~mL} / 1$ vial).

6. Place the shaker in the refrigerator and incubate the cells at $2-8{ }^{\circ} \mathrm{C}$ for approximately 15 min with shaking. After incubation, centrifuge the cells at $200-500 \times g$ for 15 min at $2-8{ }^{\circ} \mathrm{C}$ to remove the unbound microbeads. Resuspend $\sim 6 \times 10^{7}$ cells $/ \mathrm{mL}$ in PBS/EDTA buffer + $0.5 \% \mathrm{HSA}$ and transfer them to a transfer pack bag.

7. Install the tubing set in the clinical grade magnetic cell separation device by following the manufacturer's instructions, place the packs with the PBS/EDTA buffer and the transfer pack with the cell product in the instrument and spike it when instructed by the instrument.

8. Select the Depletion 1.2 protocol for the depletion of the labeled $\alpha \beta$ T cells.

9. Centrifuge the target fraction (enriched $y \delta T$ cells) and resuspend the cells in medium supplemented with $10 \%$ human $A B$ serum.

10. Take a $0.5 \mathrm{~mL}$ sample and perform a cell count and viability with $A O / P I$ stain. Bring cells to a final concentration of approximately $1 \times 10^{6}$ cells $/ \mathrm{mL}$. Take a sample of $5 \times 10^{6}$ cells of the product for flow cytometry phenotyping post-depletion. 


\section{Co-culture with aAPCs}

1. Irradiate $5 \times 10^{7}$ aAPCs/flask at 100 Gy on the X-ray generating instrument.

2. Use the aAPCs in co-culture at a 10:1 ratio with the үठ T cells. Place the irradiated aAPCs $\left(5 \times 10^{7}\right.$ cells/ flask) and $ү \delta \mathrm{T}$ cells $\left(5 \times 10^{6}\right.$ cells/flask $)$ in $1 \mathrm{~L}$ closedsystem bioreactor flasks with $1 \mathrm{~L}$ of culture medium supplemented with $10 \%$ human $A B$ serum. Seed up to 10 flasks.

3. Expand the cells in culture for 10 days in an incubator at $37{ }^{\circ} \mathrm{C}$ and $5 \% \mathrm{CO}_{2}$.

4. Monitor glucose and lactate levels every 3-4 days using strips, glucose, and a lactate meter.

5. If glucose drops to $250 \mathrm{mg} / \mathrm{dL}$, reduce the volume in the flask to $200 \mathrm{~mL}$ using a pharmaceutical pump by sterilewelding a $1 \mathrm{~L}$ transfer pack to the red line of the closed system bioreactor.

6. Mix the cells in the remaining $200 \mathrm{~mL}$, and take a 0.5 $\mathrm{mL}$ sample for cell counting and viability measurement by AO-PI staining. If the cell count is $\geq 10^{9}$, split one flask into two flasks and fill each flask up to $1 \mathrm{~L}$ with AIMV supplemented with $10 \%$ human $A B$ serum. If the cell count is $<10^{9}$, feed the cells with a fresh liter of culture medium supplemented with $10 \%$ human $A B$ serum.

7. Repeat step 3.6 for all the flasks and return them to the incubator at $37{ }^{\circ} \mathrm{C}$ and $5 \% \mathrm{CO}_{2}$. Repeat steps 3.4-3.7 every 3 to 4 days.

\section{Cell harvest}

1. At the end of 10 days in co-culture, harvest all the bioreactor flasks. Harvest 1 bioreactor flask at a time, and pool all the cells into a transfer pack of appropriate size. Sterile-weld the transfer pack to the red line of the closedsystem bioreactor, and use the pharmaceutical pump to transfer the cells into the transfer pack.

2. Remove the following quality control samples: $1 \%$ of the drug product (DP) for sterility by blood culture and gram staining; $0.5 \mathrm{~mL}$ for cell counting and viability using $\mathrm{AO} /$ $\mathrm{PI} ; 5-10 \times 10^{6}$ cells for flow cytometry (see Figure 1 for gating strategy); $0.5 \mathrm{~mL}$ for endotoxin; $0.5 \mathrm{~mL}$ for gram staining; $10^{6}$ cells spiked into $10 \mathrm{~mL}$ of spent medium for Mycoplasma testing.

3. Centrifuge the cells at $200-500 \times g$ for $15 \mathrm{~min}$ at room temperature and discard the supernatant.

4. Wash the cells in a solution of balanced crystalloid solution+ $0.5 \% \mathrm{HSA}$ at $200-500 \times \mathrm{g}$ for $15 \mathrm{~min}$ at room temperature. Resuspend them in a target volume of $100-300 \mathrm{~mL}$ of balanced crystalloid solution $+0.5 \% \mathrm{HSA}$.

\section{Release testing}

1. Perform quality control testing of the $y \delta ~ T$ cell DP for the following: purity and Identity by flow cytometry

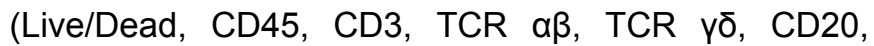
CD56, CD16); viability by $A O / P I$ staining; endotoxin; Mycoplasma testing by polymerase chain reaction (PCR); sterility by gram staining and aerobic and anaerobic blood cultures; residual K562 assay by flow cytometry (CD3- $\left.{ }^{-} \mathrm{CD} 16^{-} \mathrm{CD} 56^{-} \mathrm{CD} 71^{+}\right)$.

\section{Representative Results}

The $ү \delta T$ cell process was characterized and optimized for the production of the $ү \delta \mathrm{T}$ cell drug product. Process optimization included 1) lymphocyte enrichment using elutriation, 2) үס $\mathrm{T}$ cell drug substance (DS) cell-specific expansion with 
zoledronic acid, 3) $ү \delta \mathrm{T}$ cell DS depletion of TCRa $\beta$, 4) secondary expansion of the $\mathrm{\gamma} \delta \mathrm{T}$ cell DS using K562derived aAPCs, and 5) final DP harvest and formulation of product for administration or cryopreservation. After process optimization, confirmation runs were performed at scale using the material derived from three healthy donors to confirm cell-processing suitability. All data were analyzed and are summarized in Table 1, Table 2, and Table 3 . The cells separated from the post-counterflow centrifugation fraction 2 (F2) yielded a pure lymphocyte population with an average of 99.23\% CD45 ${ }^{+}$cells (reported as the frequency of total live gate) and excellent average viability of $95.80 \%$ (Table 1).

The $y \delta$ T-cell-specific expansion with zoledronic acid depended on the initial percentage of natural killer (NK) cells present in the lymphocyte fraction (F2) after elutriation. The enrichment of $y \delta T$ cell DS with TCRa $\beta$ depletion was consistent (Table 2). The $ү \delta ~ T$ cell DP manufactured from three healthy donors had an average of $0.11 \% \pm 0.05 \%$ CD20 ${ }^{+} \mathrm{B}$ cells and $0.00 \% \pm 0.00 \% \mathrm{TCR} \alpha \beta^{+} \mathrm{T}$ cells, thus meeting the release criterion of $\leq 1 \%$ of TCR $\alpha \beta^{+}$T cells. The average percentage of NK cells in the final product is $17.06 \% \pm 26.19 \%$ and meets the release criterion of $<35 \%$. Additionally, the average percentage of $\mathrm{T}$ cell and NK cell lineage-negative cells in the final product was $0.48 \% \pm 0.42 \%$ (Table 3). Cell surface staining and flow cytometric analysis were utilized to characterize the identity, purity, and process impurities of the DS and DP, as shown in Figure 2A-D.

The secondary expansion, achieved from the co-culture of the aAPC (K562CL6(CD3-CD137L:CD28-IL-15RA)) WCB and $y \delta T$ cell DS at a ratio of 10:1, generated a $ү \delta \mathrm{T}$ cell DP that met all release criteria, as shown in Table 4. In addition, the cells were stained and assessed by flow cytometry at Day 0-counterflow centrifugation F2 cells, Day 7-zoledronic acid-expanded T cells, Day 7-TCR $\alpha \beta$ T cell depletion, Day 17-final DP for the following biomarkers cluster of differentiation (CD)3, TCRa $\beta, T C R$ үס, CD45RA, CD45RO, CC chemokine receptor 7 (CCR7), programmed cell death protein-1 (PD-1), cytotoxic T lymphocyte-associated protein 4 (CTLA4), lymphocyte-activating gene 3 (LAG3), and T cell immunoglobulin and mucin domain-containing protein 3 (TIM3). Data shown in Figure 3 are averaged from three independent runs and demonstrate that cells have not reached exhaustion. The Moffitt CTF also developed a residual K562 assay to determine the DP impurities related to the K562-derived aAPCs (Figure 4).

The flow cytometric gating strategy used to characterize the percentages of the cell types was as follows: 1) gating on $\mathrm{T}$ and $\mathrm{NK}$ cell lineage-negative population (CD3- $\left.{ }^{-}{ }^{-} 56^{-} \mathrm{CD}^{-} 6^{-}\right)$; 2) gate on $\mathrm{CD}^{+} 1^{+}$(transferrin receptor expressed in erythroid lineage and AML allowing for the detection of residual K562 cells). This gating strategy allowed the evaluation of the $\mathrm{CD} 3^{-} \mathrm{CD} 16^{-} \mathrm{CD} 56^{-} \mathrm{CD} 71^{+}$cells, which are the aAPC (K562CL6(scFv-CD3-CD137;scFv-CD28-IL15RA)) WCB (termed "residual K562" in Figure 4). This gating allows the enumeration of residual K562 in the final DP by multiplying the frequency of residual $\mathrm{K} 562$ by the total viable count $(\mathrm{TVC})$ count of the DP $\left(\% \mathrm{CD} 71^{+} \times \mathrm{DP}\right.$ TVC $=$ Residual K562 cells in the DP). All flow cytometric data are reported as the frequency of live cells. Table 5 and Figure 4 provide the percentages of $\mathrm{T}$ cell and NK cell lineage-negative as well as residual K562 cells. A two-tailed $t$-test was performed to determine the statistical significance of the differences between these populations and revealed that there was a significant difference between WCB and $ү \delta$ T cell DP and between WCB and $\gamma \delta$ T cells $(t=0.0019$ for T cell and NK cell lineage-negative; $t<0.0001$ for Residual K562 and $t=0.0314$ 
for T cell and NK cell lineage-negative; $t<0.0001$ for Residual K562) (Table 5).
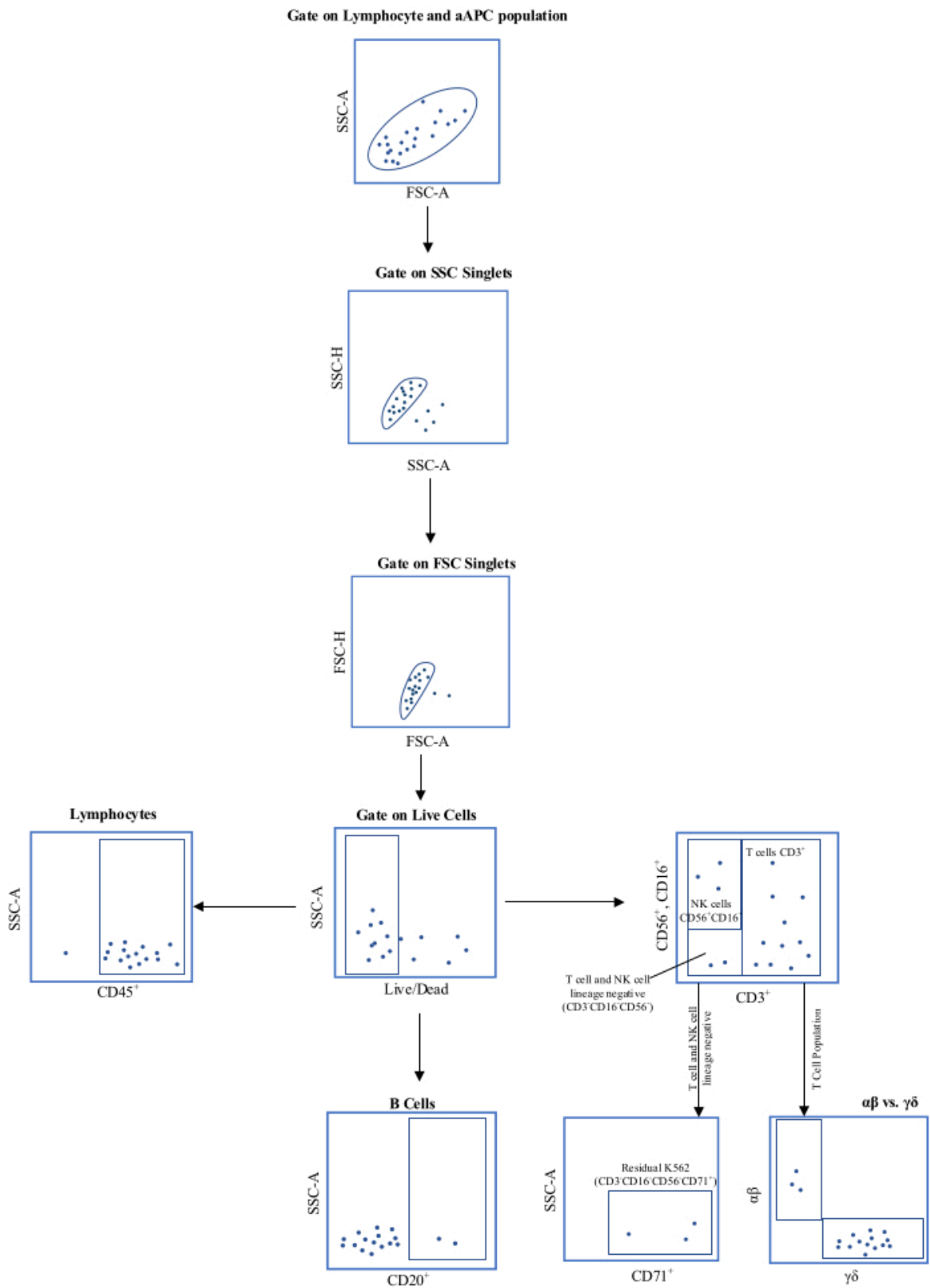

Figure 1: Schematic representation of the flow cytometric gating strategy. Abbreviations: aAPC = , artificial antigenpresenting cell; SSC-A = side scatter-area of peak; FSC-A = forward scatter-area of peak; SSC-H = side scatter-height of peak; FSC-H = forward scatter-height of peak; $\mathrm{CD}=$ cluster of differentiation. Please click here to view a larger version of this figure. 
A

CD3-CD56+CD16+ NK cells $(\%), 12.1$

CD $3+$ TCR $y \delta+$ (\%), 2.06

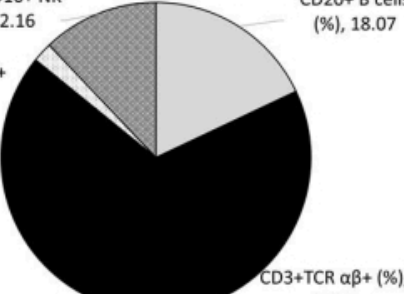

68.19

c

D7 Post-TCR $\alpha \beta$ Depletion

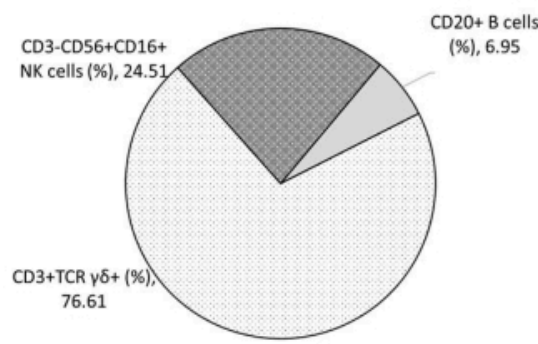

D7 Zoledronic acid-expanded

B CD20+ B cells (\%),

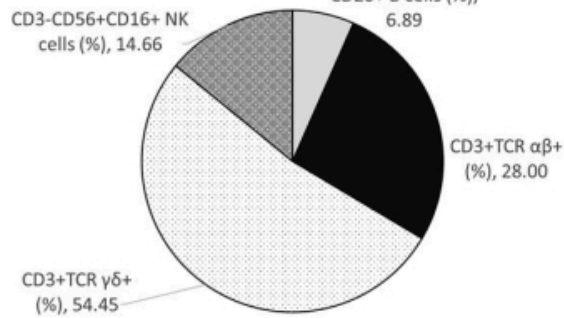

D

D17 $\gamma \delta$ T cell Drug Product

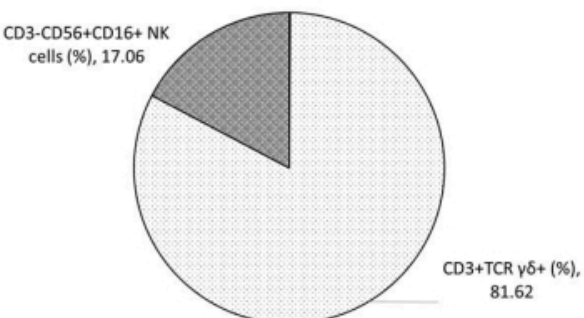

Figure 2: Composition of Starting Material, Intermediates, and Final Drug Product. All data shown are averaged from three independent runs. (A) Apheresis from healthy donors undergoes elutriation using the counterflow centrifugation device, resulting in F2 (lymphocyte-rich fraction), which is used as the starting material. (B) F2 undergoes Vy9Vס2 T cell-specific expansion for 7 days with $5 \mu \mathrm{mol} / \mathrm{L}$ of zoledronic acid and $300 \mathrm{IU} / \mathrm{mL}$ of IL-2 in $1 \mathrm{~L}$ of medium supplemented with $10 \%$ human AB serum. (C) TCR $\alpha \beta$ T cell depletion is performed on the zoledronic acid-expanded product. (D) A highly pure үठ T cell Drug Product is harvested after a second 10-day expansion with irradiated aAPCs at a 1:10 ratio with $5 \mu \mathrm{mol} / \mathrm{L}$ of zoledronic acid and $300 \mathrm{IU} / \mathrm{mL}$ of IL-2 in $1 \mathrm{~L}$ of medium supplemented with $10 \%$ human $\mathrm{AB}$ serum. Abbreviations: NK= natural killer; $C D=$ cluster of differentiation; $T C R=T$-cell receptor; IL = interleukin; aAPCs = artificial antigen-presenting cells . 


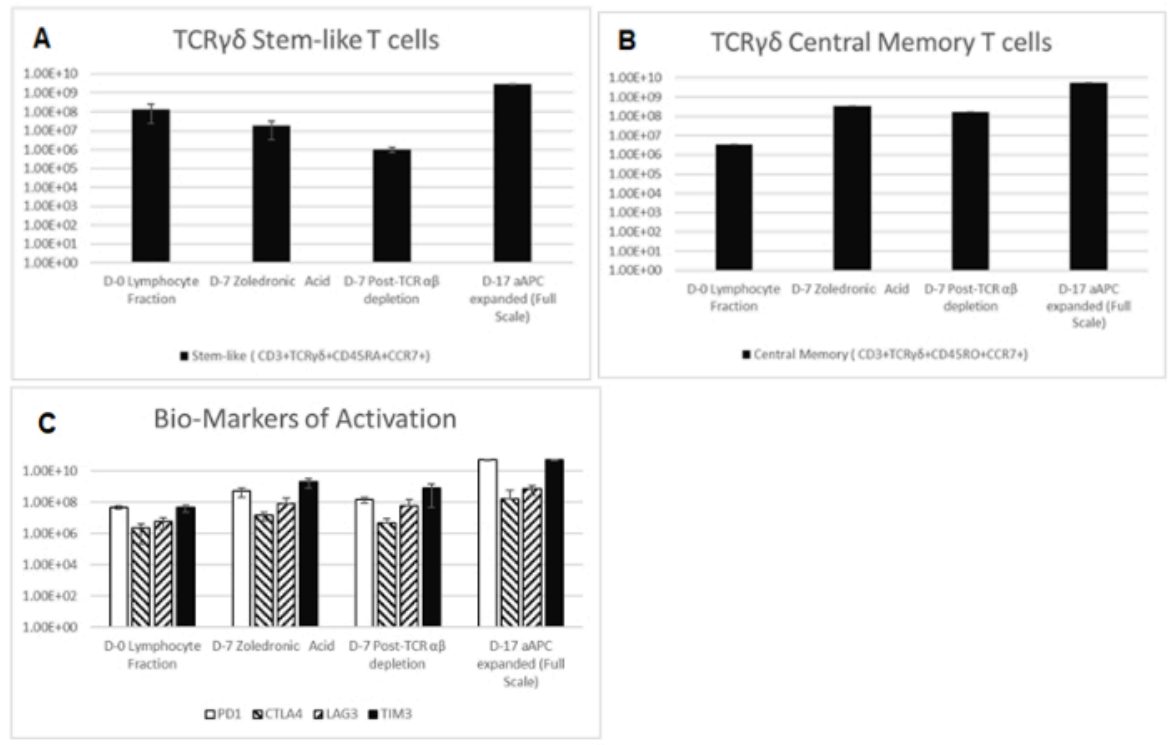

Figure 3: Biomarkers of Starting Material, Intermediates, and Final Drug Product. Cells are collected and stained for CD3, TCRaß, TCR үס, CD45RA, CD45RO, CCR7, PD-1, CTLA4, LAG3, and TIM3 at Day 0-Counterflow Centrifugation F2 cells, Day 7-zoledronic acid-expanded T cells, Day 7-TCR $\alpha \beta$ T cell depletion, Day 17-Final Drug Product. All data shown are averaged from three independent runs. (A) Stem-like $\left(\mathrm{CD}^{+}, \mathrm{TCR}_{\mathrm{\gamma} \delta^{+}}, \mathrm{CD} 45 \mathrm{RA}{ }^{+}, \mathrm{CD} 45 \mathrm{RO} \mathrm{O}^{-}\right.$, and $\left.\mathrm{CCR} 7^{+}\right)$shown as a total number of live cells. (B) Central memory $\left(\mathrm{CD}^{+}, \mathrm{TCR} \gamma \delta^{+}, \mathrm{CD} 4 \mathrm{RA} \mathrm{A}^{-}, \mathrm{CD} 45 \mathrm{RO} \mathrm{O}^{+}\right.$, and $\left.\mathrm{CCR} 7^{+}\right)$depicted as a percentage of $\mathrm{CD}^{+} \mathrm{TCR} y \delta^{+}$cells. Abbreviations: $\mathrm{CD}=$ cluster of differentiation; TCR= T-cell receptor; IL = interleukin; .CCR7 = CC chemokine receptor 7; PD-1 = programmed cell death protein-1; CTLA4 = cytotoxic $\mathrm{T}$ lymphocyte-associated protein 4; LAG3 = lymphocyte-activating gene 3; TIM3 = T cell immunoglobulin and mucin domain-containing protein 3. Please click here to view a larger version of this figure. 

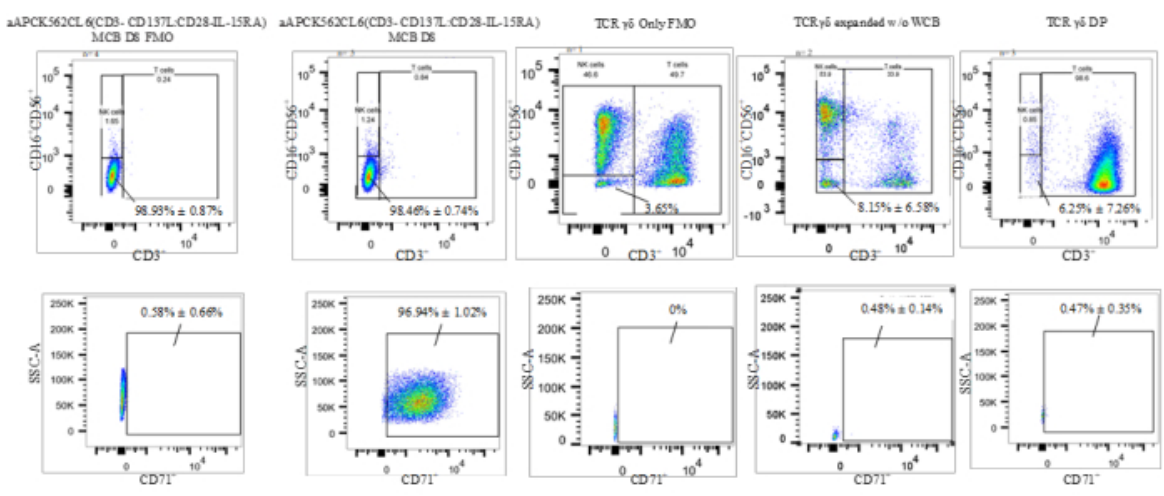

Figure 4: Representative data of a $\mathrm{K} 562$ residual assay(CD3-CD16 $\left.{ }^{-} \mathrm{CD}^{-} 6^{-} \mathrm{CD} 71^{+}\right)$. Abbreviations: aAPC $=$artificial antigen-presenting cell; NK = natural killer cell; SSC-A = side scatter-area of peak; CD = cluster of differentiation; IL = interleukin; $\mathrm{TCR}=\mathrm{T}$-cell receptor; $\mathrm{MCB}=$ master cell bank $; \mathrm{FMO}=$ fluorescence minus one; $\mathrm{DP}=$ drug product; $\mathrm{WCB}=$ working cell bank. Please click here to view a larger version of this figure. 


\begin{tabular}{|c|c|c|c|c|c|c|}
\hline \multirow{2}{*}{$\begin{array}{c}\text { Process } \\
\text { Steps }\end{array}$} & \multirow[t]{2}{*}{ Parameters } & \multicolumn{3}{|c|}{ Donors } & \multirow[t]{2}{*}{ Average } & \multirow[t]{2}{*}{ St. Dev. } \\
\hline & & Run 1 & Run 2 & Run 3 & & \\
\hline \multirow{8}{*}{$\begin{array}{c}\text { Post- } \\
\text { Enrichment } \\
\text { (Lymphocyte } \\
\text { fraction F2) }\end{array}$} & $\begin{array}{l}\text { TVC All Process Validations } \\
\text { were seeded at } 10^{9} \text { TVC }\end{array}$ & $1.00 \times 10^{9}$ & $1.00 \times 10^{9}$ & $1.00 \times 10^{9}$ & $1.00 \times 10^{9}$ & 0.00 \\
\hline & Viability (\%) & 98.6 & 96.6 & 92.2 & 95.8 & 3.27 \\
\hline & CD20 ${ }^{+} \mathrm{B}$ cells $(\%)$ & 15.6 & 23.4 & 15.2 & 18.07 & 4.62 \\
\hline & $\mathrm{CD}^{+}{ }^{+} \mathrm{T}$ cell $(\%)$ & 80.04 & 66.7 & 76.1 & 74.28 & 6.85 \\
\hline & $\mathrm{TCR} \alpha \beta^{+}(\%)$ & 77.59 & 58.03 & 68.96 & 68.19 & 9.8 \\
\hline & TCR $\gamma^{+}(\%)$ & 2.48 & 1.59 & 2.1 & 2.06 & 0.45 \\
\hline & 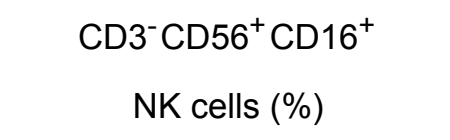 & 6.57 & 19.4 & 10.5 & 12.16 & 6.57 \\
\hline & $\begin{array}{c}\text { T cell and NK cell } \\
\text { lineage negative }(\%)\end{array}$ & 13 & 13.7 & 13.4 & 13.37 & 0.35 \\
\hline
\end{tabular}

Table 1: Summary of lymphocyte enrichment by elutriation reported as frequency of live cells. Abbreviations: TVC = total viable count; $\mathrm{TCR}=\mathrm{T}$ cell receptor; $\mathrm{CD}=$ cluster of differentiation; NK = natural killer cell. 


\begin{tabular}{|c|c|c|c|c|c|c|}
\hline \multirow{2}{*}{$\begin{array}{c}\text { Process } \\
\text { Steps }\end{array}$} & \multirow[t]{2}{*}{ Parameters } & \multicolumn{3}{|c|}{ Donors } & \multirow[t]{2}{*}{ Average } & \multirow[t]{2}{*}{ St. Dev. } \\
\hline & & Run 1 & Run 2 & Run 3 & & \\
\hline \multirow{8}{*}{$\begin{array}{c}\text { 7-day Post } \\
\text { Zoledronic } \\
\text { acid } \\
\text { Expansion } \\
\text { (pre- TCRa } \beta \\
\text { depletion) }\end{array}$} & TVC & $3.69 \times 10^{9}$ & $1.79 \times 10^{9}$ & $1.42 \times 10^{9}$ & $2.3 \times 10^{9}$ & $1.22 \times 10^{9}$ \\
\hline & Viability (\%) & 99.2 & 82.6 & 89.8 & 90.53 & 8.32 \\
\hline & CD20 ${ }^{+} \mathrm{B}$ cells & 2.1 & 11.5 & 7.08 & 6.89 & 4.7 \\
\hline & $\mathrm{CD}^{+} \mathrm{T}$ cell $(\%)$ & 95.7 & 64.1 & 91.9 & 83.9 & 17.25 \\
\hline & TCR $\alpha \beta^{+}(\%)$ & 13.88 & 38.14 & 31.98 & 28 & 12.61 \\
\hline & TCR $y \delta^{+}(\%)$ & 81.44 & 24.93 & 56.98 & 54.45 & 28.34 \\
\hline & $\begin{array}{c}\mathrm{CD}^{-} \mathrm{CD}^{-} 6^{+} \mathrm{CD} 16^{+} \\
\text {NK cells }(\%)\end{array}$ & 3.59 & 33.1 & 7.28 & 14.66 & 16.08 \\
\hline & $\begin{array}{c}\text { T cell and NK cell } \\
\text { lineage negative }(\%)\end{array}$ & 0.67 & 2.7 & 0.82 & 1.4 & 1.13 \\
\hline \multirow{10}{*}{$\begin{array}{c}\text { Post- TCR } \alpha \beta \\
\text { depletion }\end{array}$} & TVC & $1.81 \times 10^{9}$ & $4.95 \times 10^{8}$ & $3.80 \times 10^{8}$ & $8.95 \times 10^{8}$ & $7.94 \times 10^{8}$ \\
\hline & Cell viability (\%) & 98.8 & 87.6 & 89.8 & 92.07 & 5.93 \\
\hline & $\mathrm{CD}^{2} \mathrm{O}^{+} \mathrm{B}$ cells & 2.26 & 12 & 6.59 & 6.95 & 4.88 \\
\hline & $\mathrm{CD}^{+} \mathrm{T}$ cell $(\%)$ & 95.8 & 45.3 & 89.7 & 76.93 & 27.56 \\
\hline & TCR $\alpha \beta^{+}(\%)$ & 0 & 0.001 & 0.001 & 0.001 & 0.001 \\
\hline & TCR $y \delta^{+}(\%)$ & 95.61 & 45.07 & 89.16 & 76.61 & 27.51 \\
\hline & 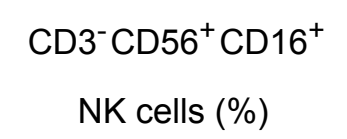 & 3.85 & 59.9 & 9.79 & 24.51 & 30.79 \\
\hline & $\begin{array}{c}\mathrm{T} \text { cell and NK cell } \\
\text { lineage negative }(\%)\end{array}$ & 0.34 & 1.72 & 0.45 & 0.84 & 0.77 \\
\hline & TCR $\alpha \beta^{+}$TVC & 0.00 & $4.95 \times 10^{3}$ & $3.8 \times 10^{3}$ & $2.92 \times 10^{3}$ & $2.59 \times 10^{3}$ \\
\hline & TCR $y \delta^{+}$TVC & $1.73 \times 10^{9}$ & $2.23 \times 10^{8}$ & $3.39 \times 10^{8}$ & $7.64 \times 10^{8}$ & $8.39 \times 10^{8}$ \\
\hline
\end{tabular}




\begin{tabular}{|l|l|l|l|l|l|}
\hline $\mathrm{CD}^{-} \mathrm{CD}^{2} 6^{+} \mathrm{CD} 16^{+} \mathrm{NK}$ TVC & $6.97 \times 10^{7}$ & $2.97 \times 10^{8}$ & $3.72 \mathrm{E}+07$ & $\mathbf{1 . 3 5 \times 1 0 ^ { 8 }}$ & $\mathbf{1 . 4 2 \times 1 0 ^ { 8 }}$ \\
\hline
\end{tabular}

Table 2: Summary of $y \delta \mathrm{T}$ cell expansion with zoledronic acid and instrument enrichment reported as frequency of live cells. Abbreviations:TVC $=$ total viable count; $T C R=T$ cell receptor; $C D=$ cluster of differentiation; NK $=$ natural killer cell. 


\begin{tabular}{|c|c|c|c|c|c|c|}
\hline \multirow{2}{*}{$\begin{array}{l}\text { Product } \\
\text { Attributes }\end{array}$} & \multirow[t]{2}{*}{ Parameters } & \multicolumn{3}{|c|}{ Donors } & \multirow[t]{2}{*}{ Average } & \multirow[t]{2}{*}{ St. Dev. } \\
\hline & & Run 1 & Run 2 & Run 3 & & \\
\hline & Day 0 yס T Cells & $2.48 \times 10^{7}$ & $1.59 \times 10^{7}$ & $2.10 \times 10^{7}$ & $2.06 \times 10^{7}$ & $4.47 \times 10^{7}$ \\
\hline & $\begin{array}{c}\text { Day } 7 \text { post } \\
\text { enrichment } ү \delta ~ T \text { Cells }\end{array}$ & $1.73 \times 10^{9}$ & $2.23 \times 10^{8}$ & $3.39 \times 10^{8}$ & $7.64 \times 10^{8}$ & $8.39 \times 10^{8}$ \\
\hline & Fold Expansion at Day 7 & 69.76 & 14.03 & 16.14 & 33.31 & 31.58 \\
\hline & TVC at harvest* & $8.14 \times 10^{10}$ & $1.67 \times 10^{10}$ & $6.84 \times 10^{10}$ & $5.55 \times 10^{10}$ & $3.42 \times 10^{10}$ \\
\hline & Cell viability (\%) & 92.8 & 85.5 & 87.3 & 88.53 & 3.80 \\
\hline & $\mathrm{CD}^{2} 0^{+} \mathrm{B}$ cells $(\%)$ & 0.12 & 0.06 & 0.15 & 0.11 & 0.05 \\
\hline & $\mathrm{CD}^{+} \mathrm{T}$ cell $(\%)$ & 97.8 & 52 & 97.5 & 82.43 & 26.36 \\
\hline & $\operatorname{TCR} \alpha \beta^{+}(\%)$ & 0 & 0.001 & 0 & 0.00 & 0.00 \\
\hline & TCR $y \delta^{+}(\%)$ & 97.51 & 50.13 & 97.21 & 81.62 & 27.27 \\
\hline & $\begin{array}{c}\mathrm{CD}^{-} \mathrm{CD}^{-} 6^{+} \mathrm{CD} 16^{+} \\
\text {NK cells }(\%)\end{array}$ & 2.16 & 47.3 & 1.71 & 17.06 & 26.19 \\
\hline & $\begin{array}{c}\text { T cell and NK cell } \\
\text { lineage negative, CD71 } \\
\text { Residual K562 }(\%)\end{array}$ & 0.018 & 0.61 & 0.82 & 0.48 & 0.42 \\
\hline & Total $ү \delta ~ T$ cells at Harvest & $7.93 \times 10^{12}$ & $8.38 \times 10^{11}$ & $6.65 \times 10^{12}$ & $5.14 \times 10^{12}$ & $3.78 \times 10^{12}$ \\
\hline & $\begin{array}{l}\text { Total Fold Expansion of } y \delta ~ T \\
\text { cells (From day } 0 \text { to Harvest) }\end{array}$ & $3.20 \times 10^{5}$ & $5.27 \times 10^{4}$ & $3.17 \times 10^{5}$ & $2.30 \times 10^{5}$ & $1.53 \times 10^{5}$ \\
\hline
\end{tabular}

*Process Validation was scaled down to flask with $5 \times 10^{6}$ y $\delta$ T cell and $50 \times 10^{6}$ irradiated aAPCs. Numbers reported are for a projected full scale run if 24 flasks are seeded from the D7 drug substance was used.

Table 3: Summary of $\mathrm{y}^{+} \mathrm{T}$ cell co-culture with aAPCs and expanded $\mathrm{y} \delta^{+} \mathrm{T}$ cell harvest reported as frequency of live cells. *Process validation was scaled down to one closed-system bioreactor ( $1 \mathrm{~L}$ capacity) with $5 \times 10^{6} \mathrm{y} \delta \mathrm{T}$ cells and $50 \times 10^{6}$ irradiated aAPCs. Numbers reported are for a projected full-scale run if 24 flasks are seeded from the D7 drug substance. Abbreviations: aAPCs $=$ artificial antigen-presenting cells; TVC = total viable count; TCR $=$ T cell receptor; CD = cluster of differentiation; NK = natural killer cell. 


\begin{tabular}{|c|c|c|c|c|}
\hline \multirow{2}{*}{ Test Parameter } & Acceptance Criteria & \multicolumn{3}{|c|}{ Results } \\
\cline { 2 - 5 } & & Validation 1 & Validation 2 & Validation 3 \\
\hline Viability & $\geq 70 \%$ & $92.80 \%$ & $85.50 \%$ & $87.30 \%$ \\
\hline Mycoplasma & Negative & Negative & Negative & Negative \\
\hline Sterility & No Growth & No Growth & No Growth & No Growth \\
Final (14 days) & Final (14 days) & Final (14 days) & Final (14 days) \\
\hline Gram stain & $\begin{array}{c}\text { No organisms } \\
\text { seen (NOS) }\end{array}$ & NOS & NOS & NOS \\
\hline Endotoxin & $\leq 2 \mathrm{EU} / \mathrm{mL}$ & $<0.50 \mathrm{EU} / \mathrm{mL}$ & $<0.50 \mathrm{EU} / \mathrm{mL}$ & $<0.50 \mathrm{EU} / \mathrm{mL}$ \\
\hline
\end{tabular}

Table 4: Summary of quality control release testing results for the $y \delta$ T cells.

\begin{tabular}{|c|c|c|c|c|c|c|c|c|}
\hline \multirow{7}{*}{$\begin{array}{c}\text { Residual } \\
\text { K562 Assay }\end{array}$} & \multicolumn{2}{|c|}{ K562 } & \multicolumn{2}{|c|}{ WCB } & \multicolumn{2}{|c|}{ үঠ Only } & \multicolumn{2}{|c|}{ yठ + WCB Product } \\
\hline & $\begin{array}{c}\mathrm{T} \text { and NK } \\
\text { cell lineage } \\
\text { neg. } \%\end{array}$ & $\begin{array}{l}\text { Residual } \\
\text { K562 \% }\end{array}$ & $\begin{array}{c}\mathrm{T} \text { and NK } \\
\text { cell lineage } \\
\text { neg. } \%\end{array}$ & $\begin{array}{l}\text { Residual } \\
\text { K562 \% }\end{array}$ & $\begin{array}{c}\mathrm{T} \text { and NK } \\
\text { cell lineage } \\
\text { neg. } \%\end{array}$ & $\begin{array}{l}\text { Residual } \\
\text { K562 \% }\end{array}$ & $\begin{array}{c}\mathrm{T} \text { and } \mathrm{NK} \\
\text { cell lineage } \\
\text { neg. } \%\end{array}$ & $\begin{array}{l}\text { Residual } \\
\text { K562 \% }\end{array}$ \\
\hline & 99.4 & 98.8 & 98.7 & 96.83 & 3.49 & 0.58 & 0.48 & 0.07 \\
\hline & 99.2 & 98.31 & 99.5 & 98.21 & 12.8 & 0.38 & 3.87 & 0.71 \\
\hline & 98.9 & 98.6 & 97.6 & 95.55 & $\mathrm{~N} / \mathrm{A}$ & $\mathrm{N} / \mathrm{A}$ & 14.4 & 0.63 \\
\hline & 99.2 & 98.9 & 97.9 & 96.53 & $N / A$ & $\mathrm{~N} / \mathrm{A}$ & N/A & $N / A$ \\
\hline & 98.7 & 98.3 & 98.6 & 97.6 & $N / A$ & $N / A$ & $\mathrm{~N} / \mathrm{A}$ & $N / A$ \\
\hline Average & 99.08 & 98.58 & 98.46 & 96.94 & 8.15 & 0.48 & 6.25 & 0.47 \\
\hline St. Dev. & 0.28 & 0.27 & 0.74 & 1.02 & 6.58 & 0.14 & 7.26 & 0.35 \\
\hline
\end{tabular}

Table 5: T cell and NK cell lineage-negative and residual K562 percentages reported as frequency of live cells. Abbreviations: NK = natural killer cell; $\mathrm{WCB}=$ working cell bank.

\section{Discussion}

The Moffit Cell Therapy Lab has developed a protocol with a biphasic expansion of highly pure $y \delta \mathrm{T}$ cells for use as a DP in clinical trials. This protocol provides a manufacturing method under cGMP guidelines in a closed system that yields a highly pure $\mathrm{\delta} \mathrm{T}$ cell DP that is successfully activated and expanded by zoledronic acid and the WCB aAPCs. This protocol has been approved by the FDA for the manufacture 
of an allogeneic $ү \delta \mathrm{T}$ cell DP for AML patients. Using healthy donors, we successfully expanded the small population of donor $ү \delta \mathrm{T}$ cells in just 7 days from $2.06 \pm 0.45 \%$ to $54.45 \pm$ $28.34 \%$. After the 7 -day expansion with zoledronic acid, it was observed that donor 2 had an increase in the NK population.

Zoledronic acid inhibits farnesyl diphosphate synthase (FDPS) in monocytes, which, in turn, leads to the accumulation of isopentenyl pyrophosphate (IPP), which has been correlated with a significant increase in the proliferation of $\mathrm{T}$ cells and natural NK cells ${ }^{7,8,9}$. This increased NK population hinders the $2^{\text {nd }}$ phase of expansion with the aAPCs, as the aAPCs will only contribute to the further expansion of NK cells. For this reason, the donor criteria were modified to exclude donors with high NK populations. After depletion of the $\alpha \beta T$ cells, the $y \delta$ T cells were further enriched to $76.61 \pm 27.51 \%$. This unique protocol includes a second expansion utilizing the Moffit-manufactured aAPCs to target the CD8, CD28, and CD127L receptors in the $ү \delta \mathrm{T}$ cells. This second expansion phase with the aAPCs yielded a DP with $\geq 65 \%$ for $\mathrm{CD}^{+}{ }^{\mathrm{TCR}} \mathrm{y}^{+}{ }^{+} \mathrm{T}$ cells, $\leq 1 \% \mathrm{TCR} \beta \mathrm{T}$, and $<35 \% \mathrm{CD}^{-} \mathrm{CD} 16^{+} \mathrm{CD}^{-} 6^{+} \mathrm{NK}$ cells. Owing to the use of K562-derived aAPCs, it was necessary to demonstrate that these aAPCs comprised $<1 \%$ of the final product.

The Moffit CTF developed a flow cytometric assay used for the release criteria to measure the percentage of the residual K562 cells in the final DP. This flow cytometric assay mitigates all the issues of utilizing cell surface antigens to identify the K562 cells. As activated T cells can express CD71, we devised a strategy to exclude all T cells and NK cells by gating on $\mathrm{CD}^{-} \mathrm{CD}^{-} 6^{-}$and $\mathrm{CD}^{-} 6^{-}$populations and then examining the $\mathrm{CD} 71^{+}$cells, which would be exclusively K562 cells. This protocol demonstrates that the $ү \delta$ T cell DP yields 0.48 $\pm 0.42 \%$ of residual $\mathrm{K} 562$ cells and meets all the release criteria of $\geq 70 \%$ viability, Mycoplasma negativity by PCR, no organisms seen by gram staining, $\leq 2 \mathrm{EU} / \mathrm{mL}$ of endotoxin, and no growth final (14 days) blood culture sterility.

\section{Disclosures}

The authors have no conflicts of interest to disclose.

\section{Acknowledgments}

We give thanks to the Cellular Immunotherapies-Investigator Initiated Trials Award Intramural Funding Opportunity from Moffitt Cancer Center for providing the funding for this protocol development. We also thank Dr. Claudio Anasetti for his invaluable help and guidance through this project. Finally, we thank Dr. Justin Boucher for his insights and review of the manuscript.

\section{References}

1. Bejanyan, N. et al. Survival of patients with acute myeloid leukemia relapsing after allogeneic hematopoietic cell transplantation: a center for international blood and marrow transplant research study. Biology of Blood and Marrow Transplantation. 21 (3), 454-459 (2015).

2. Bejanyan, N. et al. Clinical outcomes of $A M L$ patients relapsing after matched-related donor and umbilical cord blood transplantation. Bone Marrow Transplantation. 49 (8), 1029-1035 (2014).

3. Schmid, C. et al. Treatment, risk factors, and outcome of adults with relapsed AML after reduced intensity conditioning for allogeneic stem cell transplantation. Blood. 119 (6), 1599-1606 (2012).

4. Siegers, G. M. et al. Anti-leukemia activity of in vitroexpanded human gamma delta $\mathrm{T}$ cells in a xenogeneic Ph+ leukemia model. PLoS One. 6 (2), e16700 (2011). 
5. Airoldi, I. et al. үס T-cell reconstitution after HLAhaploidentical hematopoietic transplantation depleted of TCR- $\alpha \beta+/ C D 19+$ lymphocytes. Blood. 125 (15), 2349-2358 (2015).

6. Acuto, O. et al. The human T cell receptor: appearance in ontogeny and biochemical relationship of alpha and beta subunits on IL-2 dependent clones and T cell tumors. Cell. 34 (3), 717-726 (1983).

7. Xiao, L. et al. Large-scale expansion of $\mathrm{V} Y 9 \mathrm{~V} \delta 2 \mathrm{~T}$ cells with engineered K562 feeder cells in G-Rex vessels and their use as chimeric antigen receptor-modified effector cells. Cytotherapy. 20 (3), 420-435 (2018).

8. Peters, C., Kouakanou, L., Oberg, H. H., Wesch, D., Kabelitz, D. In vitro expansion of $\mathrm{V} \gamma 9 \mathrm{~V} \delta 2 \mathrm{~T}$ cells for immunotherapy. Methods in Enzymology. 631, 223-237 (2020).

9. $\mathrm{Xu}, \mathrm{Y}$. et al. Allogeneic $\mathrm{V} \gamma 9 \mathrm{~V} \delta 2 \mathrm{~T}$-cell immunotherapy exhibits promising clinical safety and prolongs the survival of patients with late-stage lung or liver cancer. Cellular \& Molecular Immunology. 18 (2), 427-439 (2021). 